\title{
Pestalotiopsis chamaeropis causing leaf spot disease of round leaf mint-bush (Prostanthera rotundifolia) in Australia
}

\author{
Azin Moslemi ${ }^{1}$ • Paul W. J. Taylor ${ }^{1}$
}

Received: 26 May 2015 / Accepted: 7 September 2015 /Published online: 14 September 2015

(C) Australasian Plant Pathology Society Inc. 2015

\begin{abstract}
Pestalotiopsis chamaeropis was isolated from necrotic leaf spots of round leaf mint-bush -Prostanthera rotundifolia (Lamiaceae) in Melbourne, Australia. Pathogenicity was confirmed by obtaining similar symptoms after inoculation of the young leaves and stems with a spore suspension of $P$. chamaeropis. Molecular analysis of the ITS, tefl and TUB genes, individually and combined, identified the pathogen as $P$. chamaeropis. The pigmentation of the median cells, number of apical and basal appendages were similar to the type isolate of $P$. chamaeropis. This is the first report of $P$. chamaeropis being a pathogen of round leaf mint-bush in Australia.
\end{abstract}

Keywords ITS · tefl · TUB · Apical · Type isolate

Prostanthera rotundifolia (Lamiaceae) is a native mint-bush plant growing in cool and temperate regions of Australia such as South Australia, Victoria, New South Wales, north and east of Tasmania (Fulton 2000; Conn 1998). The oil extracted from $P$. rotundifolia contains hexane, ethyl acetate and methanol which are antimicrobial properties and inhibit growth of bacteria such as Bacillus subtilis, Staphylococcus aureus and Escherischia coli (Dellar et al. 1994).

There are very few reports of plant pathogens causing diseases in $P$. rotundifolia. Formerly, Phytophthora cinnamomi was isolated from mint-bush but the plant was recognised as a resistant host and showed no disease symptoms (Barker and Wardlaw 1995). In 2013, young and newly grown leaves and

Paul W. J. Taylor

paulwjt@unimelb.edu.au

1 Faculty of Veterinary and Agricultural Science, University of Melbourne, Melbourne, VIC 3010, Australia stems of mint-bush plants growing in the Systems Garden at the University of Melbourne, Australia were found showing brown, water-soaked and sunken round lesions (predominately on the underside), darker in the margins, light brown-red in the centre. Chlorotic tissue occurred on the surface of the leaves but not underside. Typical symptoms of the disease were collected from the mint-bush plant and transferred to the laboratory in plastic bags for culturing and isolate identification.

Leaves were surface sterilised by immersing for $30 \mathrm{~s}$ in $80 \%$ ethanol, before transferring to $1 \%$ a.i. sodium hypochlorite for $1 \mathrm{~min}$, followed by washing in sterilised water. Sterilised leaves were then blotted with sterilised paper towel, then $2 \mathrm{~mm}^{2}$ of tissue from the margin of the lesion with healthy tissue was excised and plated onto water agar (WA) and incubated for 4 days at $23-25^{\circ} \mathrm{C}$. Mycelia that grew out of the leaves were transferred onto potato dextrose agar (PDA) and incubated for a further 7 days. Single spored colonies were obtained from isolates which were grown on PDA and incubated for 10 days at $22-24^{\circ} \mathrm{C}$. A culture of the isolate was deposited at the Queensland Plant Pathology Herbarium (BRIP), Australia.

Colony growth rate was measured for three PDA cultures at 2-day intervals. The isolate was also grown on synthetic poor nutrient agar (SNA) (Crous et al. 2009) with pieces of sterilized filter papers (double autoclaved at $121{ }^{\circ} \mathrm{C}$ for $20 \mathrm{~min}$ ) on the surface of the agar to induce sporulation. Seven days after culturing, spores were mounted in lactic acid and the conidia shape and size measured.

To confirm pathogenicity, twigs containing rosettes of young healthy leaves and stems were cut from a healthy plant; surface sterilised and then placed in plastic containers. Inoculations were by either spraying leaves with $10^{4}$ spore/ $\mathrm{mL}$, or by pipetting $20 \mu \mathrm{l}$ of spore suspension onto both sides of the leaves. Containers were sealed then incubated at 23- 
$25{ }^{\circ} \mathrm{C}$ for 7 days. Controls were inoculated with sterilised water. Leaf and stem tissue that developed necrotic lesions were cultured onto PDA until sporulation, then the pathogen's morphological characteristics were recorded.

DNA was extracted from the fungal mycelia scraped directly from 7-day-old single spored cultures on PDA using the DNeasy Plant Mini Kit (Qiagen) following the manufacture's instruction.

The internal transcribed spacer (ITS) regions was amplified using primers ITS1 and ITS4 (White et al. 1990), the partial $\beta$ tubulin (TUB) gene was amplified using primers BT2A and BT2B (Maharachchikumbura et al. 2012) and the tef1 gene was amplified using primers EF1-728 F and EF2 (Maharachchikumbura et al. 2014; O’Donnell et al. 1998; O'Donnell et al. 2010). PCR was performed using the procedure described in Maharachchikumbura et al. (2012), with a slight difference in the amount of the template DNA used, except that $10 \mathrm{ng}$ of template DNA was used for ITS and tefl; and $30 \mathrm{ng}$ for TUB genes. DNA amplification was carried out using an Eppendorf thermal cycler. PCR products were then purified using QIAquick PCR purification kit (Qiagen) and an electrophoresis gel was run after purification to test the integrity of the bands. All PCR and purification products were stained in ethidium bromide and visualised under UV light.

Purified amplicons were sent to Australian Genome Research Facility Ltd. for sequencing. Sequence intensity was assessed using ChromasLite MFS computer package and then were aligned using the multiple alignment program ClustalW.

The consensus sequences were obtained by alignment of forward and reverse sequences using MEGA6 (Tamura et al. 2013) and deposited in GenBank (Table 1). BLAST searches in GenBank using the obtained ITS, TUB and tefl sequences revealed highest similarity with multiple species of Pestalotiopsis. Therefore, to study the taxonomic placement of the isolate within Pestalotiopsis species complex, sequences of Pestalotiopsis type strains available from GenBank were retrieved for inclusion in the phylogenetic analyses (Maharachchikumbura et al. 2014); The accession numbers of all sequences are listed in Table 1.

Phylogenetic trees were constructed for each gene individually and combined in MEGA6. Trees were analysed using Maximum Parsimony (MP) statistical method. Seiridium sp. was used as the outgroup (Maharachchikumbura et al. 2012; Zhang $\mathrm{Y}$ et al. 2012). To assess the relative stability of branches, bootstrap analysis with 1000 replicates was performed. Gaps were treated as missing data.

On PDA and mint-bush stems, black, pycnidia-like conidiomata containing septated conidiospores with apical appendages developed which was typical of Pestalotiopsis species. The culture characteristics were white fluffy aerial mycelia on PDA that reached a diameter of $35-45 \mathrm{~mm}$ after a week. Black conidiomata scattered on the surface of the mycelia, were produced after 7-10 days of culturing with the reverse side white-pink colour.

The black conidiomata were mostly aggregated, globose, $>500 \mu \mathrm{m}$ diameter. The conidiospores were 4-septate (5 celled) and were fusoid to ellipsoid; second cell from the base was $4.0-5.7 \times 4.0-5.3 \mu \mathrm{m}$; third cell was $3.0-5.8 \times 5.0$ $6.9 \mu \mathrm{m}$; fourth cell was $4.0-6.0 \times 4.0-5.5 \mu \mathrm{m}$ with a total length of $19.0-27.6 \mu \mathrm{m}$. There were three median cells doliiform, 13.0-17.0 $\mu \mathrm{m}$ long, concolorous with the two upper median cells slightly darker than the median basal cell. The apical cells were hyaline, $3.5-5.7 \times 2-3.9 \mu \mathrm{m}$ with 2 to 3 unbranched, unknobed tubular apical appendages (mostly 3 ) with the average size of $15.19 \mu \mathrm{m}$. The basal cell was obconic, hyaline; 3.7-6.2 $\times 2.0-3.5 \mu \mathrm{m}$, single unbranched with a cylindrical basal appendage, $5.65 \mu \mathrm{m}$ long (Fig. 1).

Disease symptoms and infection by the mint-bush Pestalotiopsis species on both sides of the leaves were significantly higher than on the stems. On mint-bush, fewer symptoms were observed during May-August 2013 and 2014 which may have been due to lower temperatures in autumn and winter.

The underside of young leaves and stems inoculated by either spray or droplets of spores developed globose, brown and water soaked lesions after 1 week. Pestalotiopsis spores were obtained from the lesions. Cultures from infected leaves were the same as those of the Pestalotiopsis species originally isolated from mint-bush plants.

Nineteen isolate sequences were used to construct phylogenetic trees (Table 1). Combined tree of the three genes was selected out of 5 most parsimonious trees (length $=692$ ), consistency index (0.622951), retention index (0.684066), and the composite index (0.570384) for all sites and parsimonyinformative sites. There were a total of 1402 positions in the final dataset (Fig. 2). In both individual and combined trees, the mint-bush Pestalotiopsis isolate clustered with P. chamaeropis.

Individual and combined phylogenetic trees showed that the Pestalotiopsis species causing leaf spot of $P$. rotundifolia clustered with other isolates in the $P$. chamaeropis species complex. In the ITS tree (unpublished), the mint-bush isolate also clustered with $P$. linearis and $P$. intermedia along with P. chamaeropis. Maharachchikumbura et al. (2014) also reported that $P$. chamaeropis formed a sister clade with $P$. intermedia and $P$. linearis in the combined phylogeny of the three genes. Maharachchikumbura et al. (2012) reported that these three closely related species could not be separated on spore size and shape because of the large variation in these characters.

Morphological characters of the mint-bush $P$. chamaeropis showed similar characteristics to the ex-type isolate such as pigmentation of the median cells (concolourous), number of apical appendages (2-3, mostly 3$)$, basal appendages and 
Table 1 List of isolates with their accession numbers used in this study; ex-type isolates are in bold type

\begin{tabular}{|c|c|c|c|c|c|c|}
\hline Pestalotiopsis isolates & Culture collection No. & Host & Location & ITS & TUB & tef1 \\
\hline P. chamaeropis & BRIP 62468 & Prostanthera rotundifolia & $\begin{array}{l}\text { Australia } \\
\text { Melbourne }\end{array}$ & KR259104 & KR259103 & KR259102 \\
\hline P. chamaeropis & CBS 113604 & - & - & KM199323 & KM199389 & KM199471 ${ }^{\mathrm{a}}$ \\
\hline P. chamaeropis & CBS 237.38 & - & Italy & KM199324 ${ }^{\mathrm{a}}$ & KM199392 ${ }^{\mathrm{a}}$ & KM199474 \\
\hline P. chamaeropis & CBS 113607 & - & - & KM199325 & KM199390 ${ }^{\mathrm{a}}$ & KM199472 \\
\hline P. chamaeropis & CBS 186.71 & Chamaerops humilis & Italy & KM199326 ${ }^{\mathrm{a}}$ & $\mathrm{KM}_{199391^{\mathrm{a}}}$ & KM199473 \\
\hline P. australis & CBS 114193 & Grevilliae sp. & Australia; New South Wales & $\mathrm{KM} 199332^{\mathrm{a}}$ & KM199383 ${ }^{\mathrm{a}}$ & KM199475 \\
\hline P. camelliae & CBS 443.62 & Camelliae sinensis & Turkey & KM199336 ${ }^{\mathrm{a}}$ & KM199424 & KM199512 \\
\hline P. colombiensis & CBS 118553 & Eucalyptus eurograndis & Colombia & $\mathrm{KM} 199307^{\mathrm{a}}$ & KM199421 ${ }^{\mathrm{a}}$ & KM199488 \\
\hline P. grevilleae & CBS 114127 & Grevilliae sp. & Australia & KM199300 ${ }^{\mathrm{a}}$ & KM199407 & KM199504 \\
\hline P. australasiae & CBS 114141 & Protea sp. & Australia; New South Wales & KM199298 ${ }^{\mathrm{a}}$ & KM199410 & KM199501 ${ }^{\mathrm{a}}$ \\
\hline P. hollandica & CBS 265.33 & Sciodopitys verticillata & Netherlands & KM199328 & KM199388 ${ }^{\mathrm{a}}$ & KM199481 \\
\hline P. novae-hollandiae & CBS 130973 & Banksia grandis & Australia & KM199337 ${ }^{\mathrm{a}}$ & KM199425 & KM199511 \\
\hline P. intermedia & MFLUCC 12-0259 & Unidentified tree & China & JX398993 ${ }^{\mathrm{a}}$ & $\mathrm{JX} 399028^{\mathrm{a}}$ & $J X 399059^{a}$ \\
\hline P. linearis & NN0471900 & Trachelospermum sp. & China & JX398992 ${ }^{\mathrm{a}}$ & $\mathrm{JX} 399027^{\mathrm{a}}$ & $J X 399058^{a}$ \\
\hline P. rhododendri & RFRDCC 2399 & Rhodedendron sinogrande & China & $\mathrm{KC} 537804^{\mathrm{a}}$ & $\mathrm{KC} 537818^{\mathrm{a}}$ & KC537811 ${ }^{\mathrm{a}}$ \\
\hline P. telopeae & CBS 113606 & Telopea sp. & Australia & KM199295 ${ }^{\mathrm{a}}$ & KM199402 ${ }^{\mathrm{a}}$ & KM199498 \\
\hline P. unicolor & MFLUCC 12-0275 & Unidentified tree & China & JX398998 ${ }^{\mathrm{a}}$ & JX399029a & JX399063 ${ }^{\mathrm{a}}$ \\
\hline P. scoparia & CBS 176.25 & Chamaecyparis sp. & - & KM199330 ${ }^{\mathrm{a}}$ & $\mathrm{KM}_{199393^{\mathrm{a}}}$ & KM199478 \\
\hline Seiridium $\mathrm{sp}$. & - & - & - & $\mathrm{JQ683725^{ \textrm {ab } }}$ & $\mathrm{JQ683709^{ \textrm {ab } }}$ & JQ683741 ${ }^{\mathrm{ab}}$ \\
\hline
\end{tabular}

${ }^{\mathrm{a}}$ (Maharachchikumbura et al. 2014), ${ }^{\mathrm{b}}$ (Maharachchikumbura et al. 2012)

Fig. 1 a - brown water soaked lesions on the back of the leaves, b- brown pycnidia-like lesions on the young stem, c- formation of conidiomata on a mint-bush stem, d- Black conidiomata on PDA after 7 days, e- conidiogenous cells, $\mathbf{f}$ - conidiospores. Scale bars; E-F- $20 \mu \mathrm{m}$

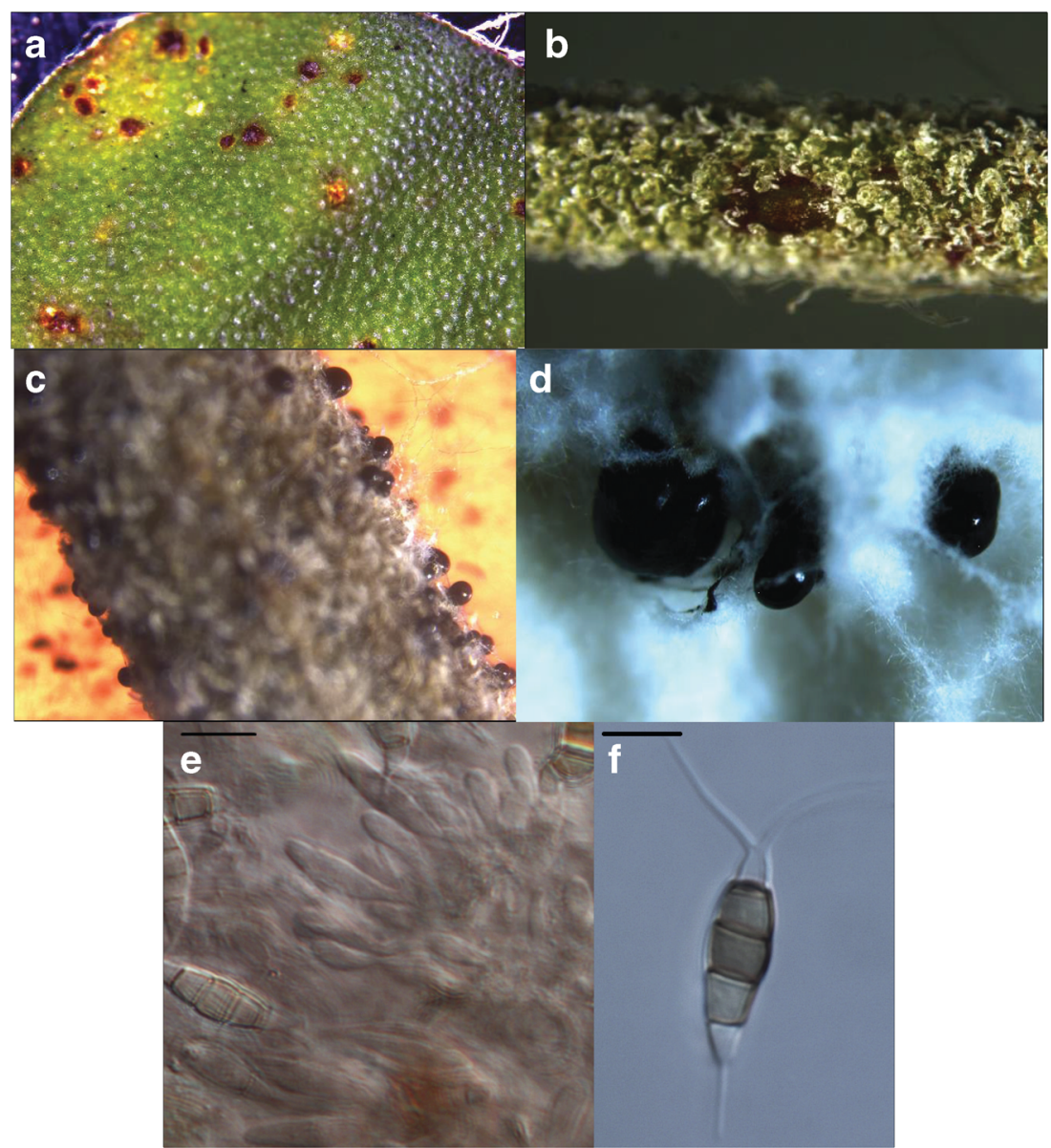


Fig. 2 Maximum Parsimony (MP) analysis of the combined ITS, TUB and tefl genes. The percentage of replicate trees in which the associated taxa clustered together in the bootstrap test (1000 replicates) is shown next to the branches (Felsenstein 1985). The MP tree was obtained using the Subtree-PruningRegrafting (SPR) algorithm. The analysis involved 19 nucleotide sequences. Consistency index $(\mathrm{CI})=0.62$; retention Index $(\mathrm{RI})=$ 0.68 . ${ }^{*}$ refers to ex-type species. Culture accession numbers were derived from

Maharachchikumbura et al. (2014)

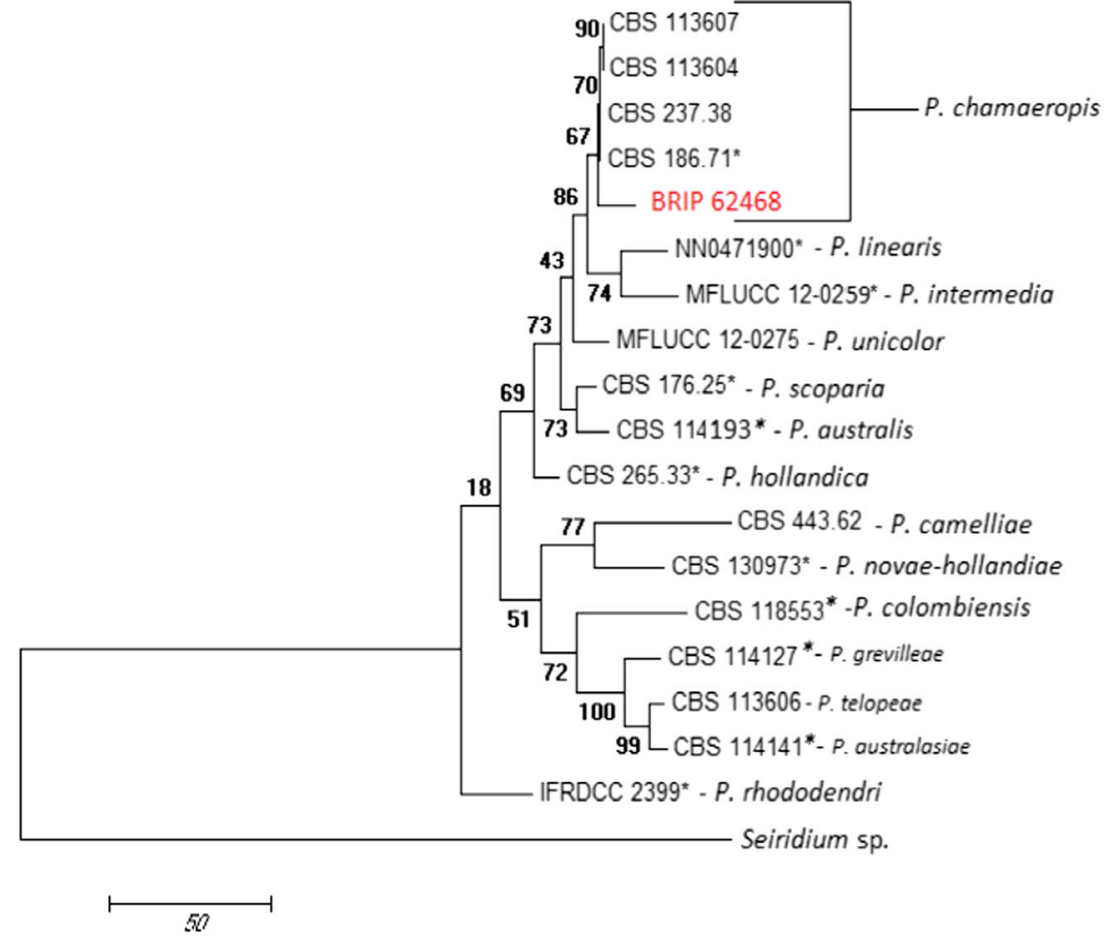

septa (4-septate) (Maharachchikumbura et al. 2014). However, the length and width of median, basal and apical cells were shorter. Jeewon et al. (2003) reported that the length of spores, median cells and appendages were not phylogenetically important in identifying the species, however, these factors might be informative in identifying species groups. In contrast, pigmentation of the median cells and appendage tip morphology were informative factors in phylogenetic identification of the species.

Most Pestalotiopsis species are pathogenic, while some are endophytes or saprobes (Wei et al. 2007). Wei et al. (2007) reported the colonisation of the leaves of Podocarpaceae, Theaceae and Taxaceae families by endophytic Pestalotiopsis species in southern China and suggested that colonisation increased with leaf age and season. High temperatures (tropical regions) favoured endophytic Pestalotiopsis species (Liu et al. 2007).

Previously it was assumed that Pestalotiopsis species were host specific (Wei et al. 2007). However, Jeewon et al. (2004) and Hyde et al. (2014) demonstrated that most species isolated from the host plant were not necessarily host-specific. Moreover, host specification and geographical location became less informative with the introduction of molecular identification (Hyde et al. 2014). P. chamaeropis was initially isolated from the leaves of dwarf palm (Herrera 1989) (Chamaerops humilis) in Italy in 1971 (Maharachchikumbura et al. 2014). Interestingly, the pathogen has not been identified on any other native plants in Australia to date and seems that it is only a pathogen of Prostanthera rotundifolia; the Australian mint-bush. However, other Pestalotiopsis species such as P. australasiae,
P. grevilliae, P. telopeae and P. novae-hollandica have been recorded as pathogens of native Australian plants (mostly isolated from the plants of Proteaceae) (Maharachchikumbura et al. 2014). Pestalotiopsis species are cosmopolite and can be isolated from different substrates. However, bioassays carried out with P. chamaeropis isolated from necrotic spots on native mint-bush, proved the pathogenicity of the isolate for the first time in Australia.

\section{References}

Barker PCJ, Wardlaw TJ (1995) Susceptibility of selected tasmanian rare plants. Phytophthora Cinnamomi 43:379-386

Conn BJ (1998) Contributions to the systematics of Prostanthera (Labiatae) in south-eastern Australia. Telopea 7:319-332

Crous PW, Verkley GJM, Groenewald JZ, Samson (2009) CBS laboratory manual series

Dellar JE, Cole MD, Gray AI, Gibbons S, Waterman PG (1994) Antimicrobial Sesquiterpenes from Prostanthera Aff Melissifolia and P.rotundifolia. Phytochemistry 36:957-960

Felsenstein J (1985) Confidence limits on phylogenies: an approach using the bootstrap. Soc Stud Evol 39:783-791

Fulton A (2000) Food safety of three species of native mint. Melbourne Northern Melbourne Institute of TAFE

Herrera J (1989) On the reproductive biology of the dwarf palm, Chamaerops humilis in Southern Spain. Principes 33:27-32

Hyde KD, Nilsson RH, Alias SA, Ariyawansa HA, Blair JE, Cai L, de Cock AWAM, Dissanayake AJ, Glockling SL, Goonasekara ID, Gorczak M, Hahn M, Jayawardena RS, van Kan JAL, Laurence MH, Levesque CA, Li XH, Liu JK, Maharachchikumbura SSN, Manamgoda DS, Martin FN, McKenzie EHC, McTaggart AR, Mortimer PE, Nair PVR, Pawlowska J, Rintoul TL, Shivas RG, Spies CFJ, Summerell BA, Taylor PWJ, Terhem RB, Udayanga 
D, Vaghefi N, Walther G, Wilk M, Wrzosek M, Xu JC, Yan JY, Zhou N (2014) One stop shop: backbones trees for important phytopathogenic genera: I (2014). Fungal Divers 67:21-125

Jeewon R, Liew ECY, Simpson JA, Hodgkiss IJ, Hyde KD (2003) Phylogenetic significance of morphological characters in the taxonomy of Pestalotiopsis species. Mol Phylogenet Evol 27:372-383

Jeewon R, Liew ECY, Hyde KD (2004) Phylogenetic evaluation of species nomenclature of Pestalotiopsis in relation to host association. Fungal Divers 17:39-55

Liu AR, Xu T, Guo LD (2007) Molecular and morphological description of Pestalotiopsis hainanensis sp. nov., a new endophyte from a tropical region of China. Fungal Divers 24:23-36

Maharachchikumbura, Guo LD, Cai L, Chukeatirote E, Wu WP, Sun X, Crous PW, Bhat DJ, McKenzie EHC, Bahkali AH, Hyde KD (2012) A multi-locus backbone tree for Pestalotiopsis, with a polyphasic characterization of 14 new species. Fungal Divers 56:95-129

Maharachchikumbura, Hyde KD, Groenewald JZ, Xu J, Crous PW (2014) Pestalotiopsis revisited. Stud Mycol 79:121-86

O’Donnell K, Kistler HC, CIGELNIK E, Ploetz R (1998) Multiple evolutionary origins of the fungus causing Panama disease of banana: concordant evidence from nuclear and mitochondrial gene genealogies. Appl Biol Sci 97:2044-2049

O'Donnell K, Sutton DA, Rinaldi MG, Sarver BAJ, Balajee SA, Schroers HJ, Summerbell RC, Robert VARG, Crous PW, Zhang N, Aoki T, Jung K, Park J, Lee YH, Kang S, Park BJ, Geiser DM (2010) Internet-Accessible DNA sequence database for identifying fusaria from human and animal infections. Am Soc Microbiol 48:37083718

Tamura K, Stecher G, Peterson D, Filipski A, Kumar S (2013) MEGA6: molecular evolutionary genetics analysis version 6.0. Mol Biol Evol 30:2725-2727

Wei JG, Xu T, Guo LD, Liu AR, Ying, Zhangand Pan XH (2007) Endophytic Pestalotiopsis species associated with plants of Podocarpaceae, Theaceae and Taxaceae in southern China. Fungal Divers 24:55-74

White TJ, Bruns T, Lee S, Taylor J (1990) Amplification and direct sequencing of fungal ribosomal RNA genes for phylogenetics. In PCR protocols : a guide to methods and applications Part three; genetic evolution, 315-322

Zhang Y, Maharachchikumbura SNHCE, McKenzieand Hyde DK (2012) A novel species of Pestalotiopsis causing leaf spots of Trachycarpus fortunei. Cryptogam Mycol 3:311-318 